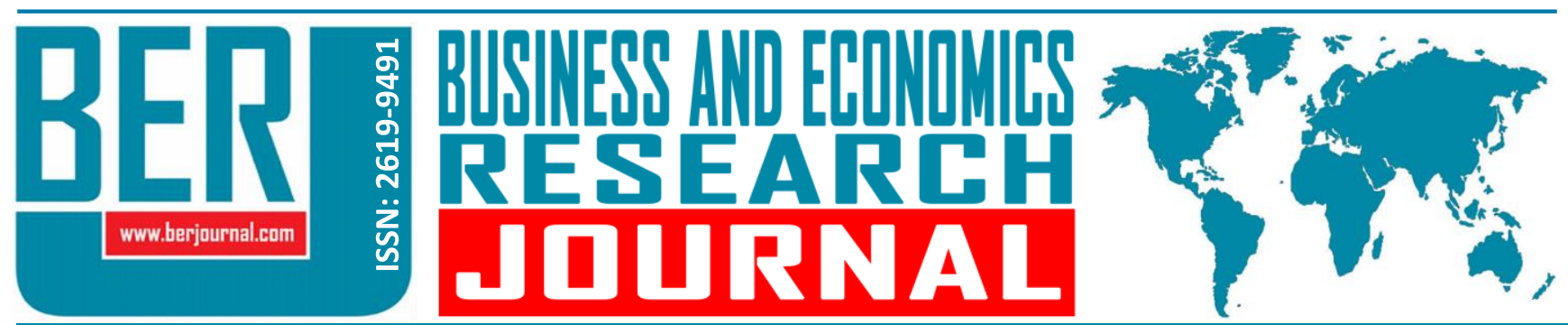

Business and Economics Research Journal Vol. 10, No. 1, 2019, pp. 115-129 doi: 10.20409/berj.2019.158

\title{
Exploring the Relationships between Environmental Uncertainty, Business Strategy and Management Control System on Firm Performance
}

\begin{abstract}
Melek Eker ${ }^{\mathrm{a}}$, Semih Eker ${ }^{\mathrm{b}}$
Abstract: The subject of this study is the effects of three way interaction between environmental uncertainty, business strategy and management control system on firm performance. The data from 94 Turkish manufacturing company of 500 top class company is analyzed with the SPSS. The results of multiple regression analysis indicate that higher differentiation strategy, management control system, the three-way interaction between environmental uncertainty, differentiation strategy and management control system and the three-way interaction between environmental uncertainty, differentiation strategy and interactive control system lead to higher firm performance. According to the results of $t$-test, the firms with high performance tend to use differentiation strategy, management control system, three-way interaction between environmental uncertainty, differentiation strategy and management control system, three-way interaction between environmental uncertainty, cost leadership strategy and management control system, three-way interaction between environmental uncertainty, differentiation strategy and interactive control system, three-way interaction between environmental uncertainty, cost leadership strategy and diagnostic control system more than ones with low performance.
\end{abstract}

Keywords: Environmental Uncertainty, Business Strategy, Management Control Systems, Financial Performance, Non-Financial Performance

JEL: L10, M40

\section{Introduction}

In today's intensely competitive environment, businesses must perform high performance. Studies show that performance improvement and sustainability are not dependent on a single factor, but on many factors (Lenz, 1980) and this increases the importance of management control systems (MCS) (Abernathy \& Guthrie, 1994; Chong \& Chong, 1997; Chenhall, 2003).

Business management need data for both internal and external environment when designing and implementing their own strategy. During the collection and processing of this data, MCS is vital for enterprises operating as a feedback system. MCS is critical in determining required operational actions, clarifying mutual expectations, determining priorities for operational improvements and also determining targets that may affect current and follow-up performance (Acquaah, 2013:131).

High performance for businesses has two meanings. The first is the highest production with low cost in stable market conditions. The second is to fully implement the differentiation strategy, which can respond

a Assoc. Prof., PhD., Uludag University, Faculty of Economics and Administrative Sciences, Department of Business Administration, Bursa, Turkiye, melekeker@uludag.edu.tr (ORCID ID: 0000-0002-0353-4855)

b Lecturer, PhD., Uludag University, Faculty of Economics and Administrative Sciences, Department of Political Science and Public Administration, Bursa, Turkiye, semiheker@uludag.edu.tr (ORCID ID: 0000-0002-0017-8437) 
to new developments and adapt itself to new situations under uncertain market conditions. For this purpose, MCS should enable enterprises to behave according to environmental conditions, in other words, they should keep the effects of contingent variables in a sustainable balance.

Depending on the strategy differentiation in stable and unstable market conditions, there are two types of MCS. These are diagnostic and interactive control system. The fact that high performance will be shown in uncertain environmental conditions makes the latter attractive for businesses. Interactive control system, beyond the traditional feedback role of MCS, is a pro-active MCS that monitors internal and external changes and developments and motivating employees by including to this proceses; encourages them to contribute to the strategy; based on continuous development and learning; constantly informs management with healthy data and allows control easier. In short, the interactive control system is a MCS that is well aligned with the characteristics of the differentiation strategy.

The aim of this study is to empirically demonstrate the role of different MCS (beliefs, behavioral, diagnostic and interactive) in achieving success of the strategy, as well as the impact of interactions between environmental uncertainty, business strategy and MCS on firm performance. The related literature and theoretical framework, methodology and findings constitute the sections of the study.

\section{Literature Review}

Environmental uncertainty, business strategy, and MCS are concepts that determine each other. Intense competition environments highlight the enterprises that can provide a harmonious coexistence between the three. In order to achieve high performance, companies should configure their strategies and MCS according to their conditions. There are studies in the literature that emphasize the importance of this (Baines \& Langfield-Smith, 2003; Bastian \& Muchlish, 2012; Junqueira, Dutra, Filho \& Gonzaga, 2016).

Increasingly competitive and uncertain environment makes firms to follow differentiation strategies. In the frame of these strategies, firms' organizational design, manufacturing technology and management accounting practices should be revised. Thanks to this revisation especially realized by using non-financial informations, advanced techniques in these three main areas can be applied and thus organizational performance will increase gradually (Baines \& Langfield-Smith, 2003; Junqueira, Dutra, Filho \& Gonzaga, 2016). In this way, Bastian and Muchlish (2012) pointed that environmental uncertainty, business strategy and organizational performance significantly positively associated, non-financial performance measurement systems significantly associated, but the financial performance measurement system is not significantly associated.

MCS should be compatible with the strategy. This compliance should be sustainable in the context of environmental uncertainty. Auzair, Sofiah Md (2011) found that cost leadership strategy was positively associated with a more bureaucratic MCS but differentiation strategy was associated with less bureaucratic MCS. In an uncertain environment less bureaucratic MCS which indicates tighter control, is a rational preference. As we see, type of MCS is associated with business strategy and environmental uncertainty. Similar observation was made by Van der Stede (2000). According to him, business units favouring a differentiation strategy (A typical feature of prospectors) undergo less rigid budgetary controls and attach more importance to a higher degree of flexibility in order to facilitate a quicker response to changes in the environment. Unlike these observations Dropulić (2013) found that type of MCS utilized by companies is associated with the business strategy, company size and type but not with environmental uncertainty.

Strategy and MCS compliance are positively reflected in the firm's performance. Abernethy and Guthrie (1994) found that effectiveness of business units is dependent on a match between design of information system and firm's strategic posture. Information systems which have the characteristics of a broad scope system were found to be more effective in firms with a strategy of continuous product/market development and innovation (differentiation strategy) than in firms which were protecting a comparatively narrow and stable product-market (cost leadership strategy). Govindarajan and Fisher (1990), found that for a cost leadership strategy, financial based control leads to higher performance while for differentiation strategy, non-financial or behaviour control leads to higher performance. Tsamenyi, Sahadev and Qiao, 
(2011) found that for those firms classified as pursuing a cost leadership strategy, the use of more financial based MCS had a positive effect on performance. Arachchilage and Smith, (2013) found that the moderating effect created by the diagnostic use of MCS is more significant when the cost leadership strategy is used for performance. Gani and Jermias (2012) found that the strategy-control systems misfit has a significantly negative correlation with both self-rated and publicly available performance measures. Results revealed that diagnostic use of performance measurement system negatively influence only the organisational learning, while the interactive use positively interacts with most of the capabilities. No indirect relationship between performance measurement system use and organisational performance was found (Theriou, Maditinos \& Theriou, 2017). Naranjo-Gil (2016) found that boundary and diagnostic control systems have primarily a positive impact on the realization of cost leadership strategy, whereas belief and interactive control systems positively affect differentiation strategy.

\section{Variables and Hypotheses}

\subsection{Environmental Uncertainty}

Environmental uncertainty makes it difficult for companies to take healthy decision. In such an environment, businesses receive the information they need as incomplete or inadequate form and fail to distinguish relevant and unrelated data (Milliken, 1987: 136).

Since the 1980s, environmental uncertainty shows its effect in three different ways: customer uncertainty, technology uncertainty and competitive uncertainty. (Kohli \& Jaworski, 1990). Customer uncertainty is the unpredictability and change in customer demands; technology uncertainty is the unpredictability of changes in technology used in production; the competitive uncertainty is the unpredictability of competitors' market activities (Çetindaş \& Çelik, 2017: 135).

Environmental uncertainty is an important factor in the formulation and implementation of the strategy. In steady and regular market conditions, firms set a strategy for creating a fixed position and maintaining this position, while on the other hand they follow a strategy of differentiation and renewal in unstable environments (Uzkurt, 2002: 2). Naturally, the full implementation of strategies depends on adequate equipment and structural features that allow adaptation to environmental conditions.

\subsection{Business Strategy}

Business strategy is the plan to achieve goals and set competitive priorities. Strategy is an important factor that directs the organization's relationship with the environment, affects the internal structure and processes of the organization and thus increases the performance of the enterprise ( Hambrick, 1980: 567).

Businesses adopt "defenders, prospectors and analyzers strategies taking into account the change rates in products and markets (Miles \& Snow (1978); "conservative" and "entrepreneurship" strategies taking into account the level of product innovation (Miller \& Friesen, 1982); "build-hold-harvest" and "divest strategies" establishing a balance between market share growth and short-term profit maximization objectives (Gupta \& Govindarajan, 1984); cost leadership, differentiation and focusing strategies to detect the style of competition in the market (Porter, 1980).

In general, enterprises follow two types of strategy: cost leadership strategy and differentiation strategy. cost leadership strategy is related to such factors that high market share, monitoring economy of scale, strict cost control, patented technologies, easy accessibility to raw material, standart product (keep the product line narrow), standard operating procedures, use of expert labor (Auzair \& Langfield-Smith, 2005; Govindarajan, 1988). In the frame of cost leadership strategy, it is aimed to maintain the current position by continuing to be the most cost-effective producer and service provider in the product and service sector.

In the differentation strategy, it is aimed to be proactive and innovative, to ensure that the offered product or service is perceived as necessary and unique by the customer, and thus to sell at the desired prices, and to compete with satisfactory profits without cost reduction (Porter, 1985). The differentiation strategy requires continuous monitoring of the environment in areas such as brand dependence, new 
product technology, product specifications, product design, customer service, distribution system, marketing approach (Dess \& Davis, 1984:475; Porter, 1985; Miller, 1988). Therefore, the companies that follow this strategy give importance to research and development, new segments and new marketing areas and in this direction make serious investments in product and service innovation (Acquaah, Adjei and Mensa-Bonsu, 2008:96)

\subsection{Management Control Systems}

MCS is a formal information system that controls the activities and strategies of the enterprises on different grounds and presents the information gathered from the internal and external environments for the decision-making mechanism (Bouwens \& Abernethy, 2000; Simons; 1994: 170). Due to system efficiency, it is possible to perform a series of functions to improve performance such as planning, budgeting, cost control, environmental scanning, competitor analysis, performance evaluation, resource allocation, and employee rewards' (Simons, 1987: 49).

Formal and informal controls (Anthony, Dearden and Bedford, 1989), results, action and personnel controls (Merchant, 1985), beliefs, boundary, diagnostic and interactive controls (Simons, 2000: 208), administrative and social controls (Hopwood, 1976), market, bureaucratic and clan controls (Ouchi, 1980: 130), planning, cybernetic, reward and compensation, administrative and cultural controls (Malmi and Brown, 2008: 291) are various types of control.

The type of control shapes the appearance of the MCS. Bureaucratic MCS is together with action, formal, tight, restricted, impersonal controls and financial information on the other hand less bureaucratic MCS is together with results, informal, loose, flexible, and interpersonal controls and non-financial information (Auzair, 2011: 237).

Our study is based on the classification of simons because it has a business strategy that focuses on how to compete and position against the competitors of the control system. These are belief, boundary, diagnostic and interactive control systems (Simons, 1994: 170). These systems consist of motivation, measurement, learning and control activities that enable an enterprise to develop creativity and cooperation and thus achieve its goal (Tessier \& Otley, 2012). Control systems are used by top managers to formalize beliefs, set boundaries on acceptable strategic behavior, define and measure critical performance variables, and motivate debate and discussion about strategic uncertainties (Simons, 1994: 169).

The belief system is a formal information system that can clearly communicate the basic values, objectives, management vision and direction expressed in the mission statements and guide and inspire employees to seek individual opportunities (Simons, 2000: 303). Considering that belief systems, as a source of inspiration for individuals, encourage search for opportunities and guide the strengthening of this process (Tessier \& Otley 2012), It is possible to say that it will facilitate the implementation of both cost leadership strategy and differentiation strategy.

The behavioral control system is the formal system consisting of minimum rules and standards determined by the senior management and must be complied with by the employees. Competition rules, codes of conduct, strategic planning systems and guidelines are in the system. These enable business activities to take place at the defined product market and at an acceptable risk level (Simons, 2000: 303).

The behavioral system provides employees with the freedom to innovate at a specific risk level. The system facilitates the implementation of the proposed cost leadership and differentiation strategies, because on the one hand it encourages search for opportunities and on the other hand limits freedom (Naranjo-Gil, 2016: 869).

The diagnostic control system is the formal information system that supports the implementation of the determined strategy, monitors the results and corrects the deviations (Simons, 1995). The main purpose of this system is to provide a predictable and predictable control of the enterprise. In this context, the diagnostic control system does not encourage continuous improvement and improvement, but monitors the effective implementation of the strategy identified. With this feature, the system responds to the needs of 
the cost strategy demanding to direct attention to the deviation areas, together with strict control of costs, economies of scale, use of effective scale facilities, standardized product presentation, limited information flow, specialized working style, simple communication and coordination mechanism (Chenhall, 2003: 150; Acquaah, 2013: 134).

The interactive control system is an information system that encourages the discovery of new opportunities, improves cooperation and coordination among employees, gives importance to work and keeps corporate learning alive. Because of these features, the interactive control system facilitates the emergence of new strategies in changing market conditions and responds quickly to perceived opportunities and threats. This system is useful for businesses operating in environments with high environmental uncertainty (Simons, 1995).

\subsection{The Interaction Between Environmental Uncertainty, Business Strategy and Management Control System}

Business strategy is the way the business chooses to overcome environmental uncertainty. Success on this path depends on the implementation of a MCS that is appropriate to their structure and decisions. The harmonious coexistence of strategy and MCS increases the ability of businesses to eliminate emerging threats or turn them into opportunities (Gschwantner \& Hiebl, 2016: 375).

\subsubsection{The Interaction Between Environmental Uncertainty, Cost Leadership Strategy and Diagnostic Control System}

The purpose of the use of MCS differs according to the market environment and adopted strategy (Miller, 1988). A company that implements a cost leadership strategy in a market with stable and low environmental uncertainty needs a diagnostic control system. Here, the enterprise focuses on the control of its results and targets a low cost. Thus, the firms, depending on the low level of workflow and environmental uncertainty, evolves into a structure that does not take risks and is very careful about decision making (Iqbal \& Sharma, 2012: 44).

Due to the low uncertainty, income-expenses can be easily estimated, performance criteria can be determined in advance, costs can be monitored effectively and diagnostic control system finds better application area because there is no need for comprehensive information about markets, products and operations (Nilsson, 2002: 45). This is not the case in high-level competition. In these environments, the diagnostic control system cannot demonstrate a complete competence in monitoring and evaluating employees, production processes and the overall performance of firms (Young \& Selto, 1991), it functions as a scorecard function focusing on the evaluation and retention of historical data rather than helping to reveal new strategies. In other words, it is insufficient and inefficient in terms of quality, time, cost, innovation and flexibility (Kaplan, 1983; Thomas, 1990: 63; Sim \& Koh, 2001).

\subsubsection{The Interaction Between Environmental Uncertainty, Differentiation Strategy and Interactive Control System}

In a dynamic and variable competitive environment, businesses need an interactive control system (Miller, 1988; Iqbal \& Sharma, 2012: 45). The reason for this is that firms care about discussing the decisions they made with the purpose of offering different, unique products or service, in other words they prefer a differentiation strategy (Frigotto, Coller, \& Collini, 2013).

The interactive control system provides all employees with operational and strategic information on what they need to do today to differentiate the business from other businesses in the sector and create value for the customer; provides the opportunity to identify problems and propose solutions in their fields; imposes autonomy and responsibility on employees; conducts control through coordination; increase the dialogue among employees; and thus the emergence of new ideas and strategies (Merchant \& Bruns, 1986; Wruck \& Jensen, 1998; Chenhall, 1997) Thus, interactive use can create a problem-solving teamwork environment by 
analyzing the performance data based on real time basis, communicating the necessary information to the relevant people and adapting the existing strategy to changing new conditions.

As a result of differentiation strategy, firms need information about competitor tactics, developments in technology, new customer demands, differences in existing demands, new product and service development, cost reduction paths, estimation of income-expenses, growth of the enterprise and whether such growth continues. In this context, the business management executing the interactive control system can monitor the activities that are critical for the development of the company with current and continuous data from internal and external environment, and monitor the uncertainties in the future and manage them effectively.

Accordingly, in this study the following hypothesis are tested:

$\mathrm{H} 1$ : There is a positive and significant relationship between environmental uncertainty and firm performance.

$\mathrm{H} 2$ : There is a positive and significant relationship between business strategy and firm performance.

H3: There is a positive and significant relationship between MCS and firm performance.

$\mathrm{H} 4$ : The three-way interaction between environmental uncertainty, differentiation strategy and MCS has a significant effect on firm performance.

H5: The three-way interaction between environmental uncertainty, cost leadership strategy and MCS has a significant effect on firm performance.

H6: The three-way interaction between environmental uncertainty, differentiation strategy and interactive control system has a significant effect on firm performance.

H7: The three-way interaction between environmental uncertainty, differentiation strategy and diagnostic control system has a significant effect on firm performance.

H8: The three-way interaction between environmental uncertainty, cost leadership strategy and interactive control system has a significant effect on firm performance.

H9: The three-way interaction between environmental uncertainty, cost leadership strategy and diagnostic control system has a significant effect on firm performance.

\section{Methodology}

\subsection{The Nature of the Research and Sampling}

This study used data from 469 manufacturing enterprises ranked among the top 500 in Turkey. The data forms of the study were sent on 21 May 2016 by mail to the top managers (general manager or vice general managers) of the manufacturing firms that participated. Data were collected in about 40 days and entered into the SPSS. The survey form return rate was $20 \%(94)$.

\subsection{Data Collection Tools}

In the first part, to assess environmental uncertainty (EU) within the context of market, technology, and competitive, we used the scale developed by Desarbo, Benedetto, Song \& Sinha (2005). The survey participants were asked to indicate their ideas on a five-point scale, ranging from 1, "strongly disagree", to 5, "strongly agree". To determine the factors that form the EU, 18 items were subjected to principal component analysis and "varimax" as a rotation technique. In the analysis, the variables with the least variance $(3,4,10,18)$ and factors with single variable $(5,6)$ was removed, and factor analysis was recalculated. As a result, the Kaiser-Meyer-Olkin (KMO) measurement of sampling adequacy was 0.769 . In the analysis, three factors were determined to have eigenvalues greater than 1 . These factors explained $70.566 \%$ of the total variance. The results of the factor analysis are shown in Table 1. The Cronbach's alpha coefficients of technology uncertainty (TU), competitive uncertainty (CU), market uncertainty (MU) were $89.7 \%, 80.0 \%$ and 
$86.8 \%$, respectively, indicating very high internal reliability for the scales. An overall measurements of TU, $\mathrm{CU}$, and $\mathrm{MU}$ were constructed based on the averages of items that loaded on these factors.

Table 1. Factor Analysis of Environmental Uncertainty Scale

\begin{tabular}{|l|c|c|c|}
\hline Questions & TU & CU & MU \\
\hline Technology in our industry is changing rapidly. & 0.798 & & \\
\hline $\begin{array}{l}\text { Technological changes offer great opportunities in our } \\
\text { industry. }\end{array}$ & 0.838 & & \\
\hline $\begin{array}{l}\text { Thanks to the technological developments in our industry, it } \\
\text { is possible to develop many new products. }\end{array}$ & 0.848 & & \\
\hline Technological developments in our industry are rather minor. & 0.829 & & \\
\hline Technological changes are very frequent in our sector. & 0.850 & & \\
\hline There is a cutthroat competition in our sector. & & 0.732 & \\
\hline There are intense "promotion wars" in our industry. & & 0.588 & \\
\hline $\begin{array}{l}\text { Others can easily imitate what a company does in our } \\
\text { industry. }\end{array}$ & & 0.762 & \\
\hline Price competition is a distinctive feature of our sector. & & 0.804 & \\
\hline One hears of a new competitive move almost every day. & & 0.825 & \\
\hline $\begin{array}{l}\text { In our industry, customers' product preferences change over } \\
\text { time. }\end{array}$ & & & 0.930 \\
\hline Our customers always tend to look for new products. & & & 0.828 \\
\hline
\end{tabular}

In the second part, the design role of the MCS (belief and boundary) were measured, based on the study by Widener (2007). The respondents were asked to indicate the extent to which their firms currently use various management control initiatives on a five-point scale, ranging from 1, "never", to 5, "too often". To determine the factors that form the design role of the MCS, 8 items were subjected to principal component analysis and "varimax" as a rotation technique. In the analysis, the Kaiser-Meyer-Olkin (KMO) measurement of sampling adequacy was 0.807 . At the end of the analysis, two factor was determined to have an eigenvalue above 1 . This factor explained $74.090 \%$ of the total variance. The results of the factor analysis are shown in Table 2. The Cronbach's alpha coefficients of beliefs and boundary control system were $85.7 \%$ and $88.1 \%$ respectively, indicating very high internal reliability for the scales. The beliefs and boundary control system were constructed based on the averages of items that loaded on these factors.

Table 2. Factor Analysis of Beliefs and Boundary Control System Scales

\begin{tabular}{|l|c|c|}
\hline Questions & Boundary & Beliefs \\
\hline $\begin{array}{l}\text { Our code of business conduct informs our workforce about behaviors } \\
\text { that are off-limits. }\end{array}$ & 0.873 & \\
\hline Our workforce is aware of the firm's code of business conduct & 0.839 & \\
\hline $\begin{array}{l}\text { Our Firm relies on a code of business conduct to define appropriate } \\
\text { behavior for our workforce. }\end{array}$ & 0.829 & 0.775 \\
\hline $\begin{array}{l}\text { Our Firm has a system that communicates to our workforce risks that } \\
\text { should be avoided. }\end{array}$ & & 0.890 \\
\hline $\begin{array}{l}\text { Our mission statement clearly communicates the Firm's core values to } \\
\text { our workforce. }\end{array}$ & & 0.796 \\
\hline Top managers communicate core values to our workforce. & & 0.759 \\
\hline Our mission statement inspires our workforce. & & 0.720 \\
\hline Our workforce is aware of the Firm's core values & & \\
\hline
\end{tabular}


In the second part, the implementation role of MCS (diagnostic and interactive) were measured, based on the study by Acquaah (2013). The diagnostic control system (DCS) was evaluated using nine items. A factor analysis of the nine items was subjected to principal component analysis and "none" as a rotation technique. In the analysis, the variable with the least variance was removed, and factor analysis was recalculated. As a result, the Kaiser-Meyer-Olkin (KMO) measurement of sampling adequacy was 0.884 . At the end of the analysis, one factor was determined to have an eigenvalue above 1 . This factor explained $71.837 \%$ of the total variance. The results of the factor analysis are shown in Table 3. The Cronbach's alpha coefficient of DCS was $89.2 \%$, indicating very high internal reliability for the scale. An overall measurement of DCS was constructed by averaging the responses of the eight individual items.

Table 3. Factor Analysis of Diagnostic Control System Scale

\begin{tabular}{|l|c|}
\hline Questions & DCS \\
\hline Monitoring employees' attitudes towards budgetary items & 0.833 \\
\hline Identifying and analysing the firm's key performance indicators & 0.822 \\
\hline $\begin{array}{l}\text { Rarely following up on exception reports with significant expectations and } \\
\text { initiating actions to get things back on track }\end{array}$ & 0.798 \\
\hline $\begin{array}{l}\text { Requiring managers to prepare monthly or quarterly statements and to report } \\
\text { actual accomplishments and comparing them with planned goals }\end{array}$ & 0.791 \\
\hline Using feedback systems to track performance goals & 0.789 \\
\hline Setting goals for the company's annual profit plans & 0.765 \\
\hline Rarely reviewing monthly or quarterly exception reports & 0.745 \\
\hline Using incentives as a way of motivating employees to achieve their goals & 0.545 \\
\hline
\end{tabular}

The interactive control system (ICS) consisted of seven items. A factor analysis of the seven items was subjected to principal component analysis and "none" as a rotation technique. In the factor analysis, the Kaiser-Meyer-Olkin (KMO) measurement of sampling adequacy was 0.910. At the end of the analysis, one factor was determined to have an eigenvalue greater than 1 . This factor explained $67.961 \%$ of the total variance. The results of the factor analysis are shown in Table 4. The Cronbach's alpha coefficient of ICS was $92.2 \%$, indicating very high internal reliability for the scale. An overall measurement of ICS was constructed by averaging the responses of the seven individual items.

Table 4. Factor Analysis of Interactive Control System Scale

\begin{tabular}{|l|c|}
\hline Questions & ICS \\
\hline $\begin{array}{l}\text { Using information generated from annual profit plans, budgets, and other issues to create new } \\
\text { action plans }\end{array}$ & 0.895 \\
\hline $\begin{array}{l}\text { Frequently involving managers in face-to-face discussions of the information generated from } \\
\text { annual profit plans, budgets, and other issues at all levels to address future strategic } \\
\text { uncertainties }\end{array}$ & 0.885 \\
\hline $\begin{array}{l}\text { Continuously addressing information generated from annual profit plans, budgets, and other } \\
\text { issues on a recurring basis at the highest level of the company }\end{array}$ & 0.876 \\
\hline $\begin{array}{l}\text { Using information generated from annual profit plans, budgets, and issues to guide the search } \\
\text { for new opportunities and to stimulate experimentation and learning }\end{array}$ & 0.859 \\
\hline $\begin{array}{l}\text { Engaging managers at all levels of the organization to focus their attention frequently and } \\
\text { regularly on budgets and key performance indicators }\end{array}$ & 0.838 \\
\hline $\begin{array}{l}\text { Debating the underlying data, assumptions and action plans before setting the company's } \\
\text { performance goals }\end{array}$ & 0.811 \\
\hline $\begin{array}{l}\text { Continuously monitoring customer needs and market changes to take advantage of emerging } \\
\text { opportunities and to mitigate unexpected threats }\end{array}$ & 0.555 \\
\hline
\end{tabular}

In the third part, to measure business strategy (BS), we used the instrument developed by Acquaah (2013). The questionnaire asked respondents to indicate, on a five-point scale, the extent to which their businesses implemented 16 competitive methods over the past three years. To determine the factors that 
form the business strategy, 16 items were subjected to principal component analysis and "varimax" as a rotation technique. In the analysis, the Kaiser-Meyer-Olkin (KMO) measurement of sampling adequacy was 0.912. At the end of the analysis, two factors were determined to have eigenvalues greater than 1 . These factors explained $63.109 \%$ of the total variance. The results of the factor analysis are shown in Table 5 . The differentiation (DS) and cost leadership strategy (CS) were generated based on the averages of items that loaded on these factors.

Table 5. Factor Analysis of Business Strategy Scale

\begin{tabular}{|l|c|c|}
\hline Business Strategy & DS & CS \\
\hline Advertising and promotion of products and services & 0.812 & \\
\hline Building brand and company identification & 0.809 & \\
\hline Effectively controlling distribution channels & 0.760 & \\
\hline Offering specialty products and services & 0.741 & \\
\hline Offering a broad range of products or services & 0.738 & \\
\hline Innovation in the marketing of products and services & 0.724 & \\
\hline Developing new products or services & 0.610 & \\
\hline Improving existing customer service & 0.607 & \\
\hline Creating products or services for high priced market segments & 0.515 & \\
\hline Controlling operating and overhead costs & & 0.798 \\
\hline Operating efficiently & & 0.789 \\
\hline Innovating in product process or services & & 0.754 \\
\hline Emphasizing high quality standards or high quality services & & 0.744 \\
\hline Offering competitive prices for products and services & & 0.727 \\
\hline Forecasting market growth in sales & & 0.607 \\
\hline Upgrading or refining existing products. & 0.557 \\
\hline
\end{tabular}

In the last part, top managers were asked to indicate on nine-point Likert scales, ranging from "well below average" to "well above average", their assessment of their firms' performance compared with their major competitors. A factor analysis of the ten items was used for principal component analysis, and "varimax" was used as the rotation technique. In the analysis, the KMO measurement of sampling adequacy was 0,882 . At the end of the analysis, two factors were determined to have eigenvalues greater than 1 . This factor explained $73.186 \%$ of the total variance. The results of the factor analysis are indicated in Table 6 . It is seen that the first factor contains financial information, and the second factor includes the non-financial performance variables. The Cronbach's alpha coefficients of the financial and non-financial performances of firms were $91.7 \%$ and $87.7 \%$, respectively, indicating very high internal reliability for the scales. The financial and non-financial performances were constructed based on the averages of items that loaded highly on these factors.

Table 6. Factor Analysis of Firm Performance Scale

\begin{tabular}{|l|c|c|}
\hline Performance Measurements & Financial Perf. & Non-Financial Perf. \\
\hline Return on assets & 0.928 & \\
\hline Operating income & 0.921 & \\
\hline Return on investment & 0.897 & \\
\hline Cash flow operations & 0.665 & \\
\hline Cost of sales ratio & 0.596 & 0.874 \\
\hline Market development & & 0.846 \\
\hline Market share & & 0.781 \\
\hline New product development & & 0.709 \\
\hline Human resource development & & 0.657 \\
\hline Sales growth & & \\
\hline
\end{tabular}




\subsection{Data Analysis}

In this study, the data were entered into SPSS software, version 13 (Chicago, IL, USA), for data analysis. Multi correlation, multiple regression analysis and independent-samples t-test analysis were performed.

\subsubsection{Descriptive Statistics and Correlation Analysis for All Variables}

Table 7 presents the descriptive statistics for the independent and dependent variables of this study.

Table 7. Descriptive Statistics for All Variables

\begin{tabular}{|l|c|c|c|c|c|}
\hline Variables & N & Min. & Max. & Mean & Std. Deviation \\
\hline Environmental Uncertainty (Average of TU, CU, MU) & 94 & 1.60 & 4,70 & 3,3257 & 0.67142 \\
\hline Differentiation Strategy (DS) & 94 & 1.43 & 5.00 & 3.8381 & 0.75369 \\
\hline Cost Leadership Strategy (CS) & 94 & 1.00 & 5.00 & 3.4127 & 0.92989 \\
\hline Beliefs CS & 94 & 2.50 & 5.00 & 4.1055 & 0.62507 \\
\hline Boundary CS & 94 & 1.00 & 5.00 & 4.1569 & 0.70994 \\
\hline Interactive Control Systems (ICS) & 94 & 1.14 & 5.00 & 3.8571 & 0.82239 \\
\hline Diagnostic Control Systems (DCS) & 94 & 1.38 & 5.00 & 3.9757 & 0.72576 \\
\hline MCS (Average of Beliefs, Boundary, ICS, DCS) & 94 & 2.38 & 5.00 & 4.0238 & 0.58694 \\
\hline Financial Firm Performance (FP) & 92 & 1.40 & 8.60 & 6.2739 & 1.50420 \\
\hline Non- Financial Firm Perf. (Non-FP) & 93 & 2.00 & 9.00 & 6.4849 & 1.49550 \\
\hline General Firm Performance & 93 & 1.70 & 8.30 & 6.3802 & 1.34486 \\
\hline
\end{tabular}

According to above data, EU average score was 3.3257. DS and CS average scores were 3.8381 and 3.4127, respectively. While the MCS mean score was 4.0238, The averages of MCS sub-dimensions were $4.1055,4.1569,3.8571$ and 3.9757 , respectively. The average of financial, non-financial and general performance were $6.2739,6.4849$ and 6.3802 , respectively. These average figures show us that the firms using variables are at an above average level.

Table 8. Correlation Analysis for All Variables

\begin{tabular}{|l|c|c|c|c|c|c|c|c|c|c|}
\hline Variables & EU & DS & CS & MCS & $\begin{array}{c}\text { EUxDSx } \\
\text { MCS }\end{array}$ & $\begin{array}{c}\text { EUxCSx } \\
\text { MCS }\end{array}$ & $\begin{array}{c}\text { EUxDSx } \\
\text { ICS }\end{array}$ & $\begin{array}{c}\text { EUxDSx } \\
\text { DCS }\end{array}$ & $\begin{array}{c}\text { EUxCSx } \\
\text { ICS }\end{array}$ & $\begin{array}{c}\text { EUxCSx } \\
\text { DSC }\end{array}$ \\
\hline FP & -.003 & $.301^{* *}$ & .164 & $.337^{* *}$ & $.265^{* *}$ & $.197^{*}$ & $.275^{* *}$ & $.240^{*}$ & $.213^{*}$ & $.183^{*}$ \\
\hline Non-FP & $.232^{*}$ & $.518^{* *}$ & $.485^{* *}$ & $.367^{* *}$ & $.498^{* *}$ & $.499^{* *}$ & $.482^{* *}$ & $.477^{* *}$ & $.484^{* *}$ & $.479^{* *}$ \\
\hline Gn.Perf. & .129 & $.455^{* *}$ & $.360^{* *}$ & $.388^{* *}$ & $.424^{* *}$ & $.386^{* *}$ & $.422^{* *}$ & $.399^{* *}$ & $.388^{* *}$ & $.368^{* *}$ \\
\hline
\end{tabular}

** Correlation is significant at the 0.01 level (2-tailed).

* Correlation is significant at the 0.05 level (2-tailed).

In Table 8, the correlations between EU, business strategy (BS), MCS, interaction terms ${ }^{1}$ and firm performance were presented. According to this result, financial firm performance is positively and significantly correlated with DS, MCS, the EUxDSxMCS interaction term, the EUxCSXMCS interaction term, the EUxDSxICS interaction term, the EUxDSxDCS interaction term, the EUxCSxICS interaction term and the EUxCSxDCS interaction term. Table shows that non-financial firm performance are positively and significantly associated with all the above variables. Additionally, general firm performance is positively and significantly related to all the above variables except the EU variable. 


\subsubsection{Multiple Regression Analysis}

The multiple regression analysis was used to test the effect of EU, BS, MCS, interaction terms on firm performance. The models are presented below in equation form:

$\mathrm{Y}=\mathrm{b} 0+\mathrm{b} 1 \mathrm{X} 1+\mathrm{b} 2 \mathrm{X} 2+\mathrm{b} 3 \mathrm{X} 3+\mathrm{b} 4 \mathrm{X} 4+e$

$\mathrm{Y}=\mathrm{b} 0+\mathrm{b} 1 \mathrm{X} 1 * \mathrm{X} 2 * \mathrm{X} 4+\mathrm{b} 2 \mathrm{X} 1 * \mathrm{X} 3 * \mathrm{X} 4+e$

$Y=b 0+b 1 X 1 * X 2 * X 5+b 2 X 1 * X 3 * X 5+b 3 X 1 * X 2 * X 6+b 4 X 1 * X 3 * X 6+e$

Where:

$\mathrm{Y}=$ General Firm Performance.

$\mathrm{X} 1=\mathrm{EU}, \mathrm{X} 2=\mathrm{DS}, \mathrm{X} 3=\mathrm{CS}, \mathrm{X} 4=\mathrm{MCS}, \mathrm{X} 5=\mathrm{ICS}, \mathrm{X} 6=\mathrm{DCS}$.

$e=$ Error term

Table 9. Regressions Results of EU, BS, MCS and Interaction Terms on Firm Performance

\begin{tabular}{|c|c|c|c|c|c|}
\hline Model & $\begin{array}{l}\text { Predictor } \\
\text { Variables }\end{array}$ & $\begin{array}{c}\text { Non-Std. } \\
\text { Beta }\end{array}$ & $\begin{array}{l}\text { Std. } \\
\text { Beta }\end{array}$ & T value & $\mathbf{P}$ \\
\hline \multirow[t]{3}{*}{ I.Model } & (Constant) & 1.679 & & 1.852 & 0.067 \\
\hline & DS & 0.636 & 0.356 & 3.576 & 0.001 \\
\hline & MCS & 0.559 & 0.243 & 2.441 & 0.017 \\
\hline \multicolumn{6}{|c|}{ Dep.Variable: General Perf.; F=15.475; $\mathrm{p}=.000 ; \mathrm{R}=0.506$; Adjusted $\mathrm{R}_{2}=0.239 ;$ Durbin-Watson=1.549. } \\
\hline \multirow[t]{2}{*}{ II.Model } & (Constant) & 4.844 & & 13.199 & .000 \\
\hline & EUxDSxMCS & 0.029 & 0.424 & 4.461 & .000 \\
\hline \multicolumn{6}{|c|}{ Dep.Variable: General Perf.; F=19.896; $\mathrm{p}=.000 ; \mathrm{R}=0.424 ;$ Adjusted $\mathrm{R}_{2}=0.170 ;$ Durbin-Watson=1.637. } \\
\hline \multirow[t]{2}{*}{ III.Model } & (Constant) & 5.043 & & 15.410 & .000 \\
\hline & EUxDSxICS & 0.026 & 0.422 & 4.435 & .000 \\
\hline
\end{tabular}

According to the results of Model I, the DS and MCS terms are significant on firm performance. The standardised beta values means DS and MCS have impact firm performance positively. The beta coefficient are $0.356(\beta \neq 0)$ and $0.243(\beta \neq 0)$. Hypothesis $\mathrm{H} 2$ and $\mathrm{H} 3$ are supported. DS and MCS are associated with increasing firm performance. However, the relationship between firm performance and EU and CS could not be determined. The model explained $23.9 \%$ of firm performance score.

The results of Model II show that the standardised beta coefficient for the three-way interaction between EU, DS and MCS is positive and highly significant $(B=424 ; t=4.461, p=0.000)$. Firm performance scores increase, while the interaction between EU, DS and MCS increase. Accordingly, as $B \neq 0$, hypothesis $\mathrm{H} 4$ is accepted. But, the three-way interaction between EU, CS and MCS is found to have no significant impact on firm performance. The model explained $17 \%$ of the variance of firm performance score.

The results of Model III in tablo 9 show that the three-way interaction between EU, DS and ICS term has a positive and significant effect on firm performance $(\beta=0.422, t=4.435, p=0.000)$. In other words, higher interactions between EU, DS and ICS is associated with increasing firm performance. Accordingly, hypothesis $\mathrm{H} 6$ is supported. On the other hand, H7, $\mathrm{H} 8$ and $\mathrm{H} 9$ hypothesises are not supported. The model explained $16.9 \%$ of the variance of firm performance score. 


\subsubsection{Results of t-test Analysis}

In this section, we explore whether EU, BS, MCS and three-way interaction terms vary between low and high performance. With this aim, t-test analysis was performed, and the results of the analysis are presented in Table 10.

Table 10. Mean (SD) and t-test for BS, MCS and Interaction Terms Between High and Low Performance.

\begin{tabular}{|c|c|c|c|c|c|c|}
\hline Variables & $\begin{array}{c}\text { Firms } \\
\text { having low } \\
\text { financial } \\
\text { perf. } \\
\text { Mean } \\
\text { (n=40) } \\
\text { t-value } \\
\end{array}$ & $\begin{array}{c}\text { Firms } \\
\text { having high } \\
\text { financial } \\
\text { perf. } \\
\text { Mean } \\
\text { (n=52) } \\
\text { Sig. }\end{array}$ & $\begin{array}{c}\text { Firms having } \\
\text { low non- } \\
\text { financial } \\
\text { perf. } \\
\text { Mean } \\
\text { (n=47) } \\
\text { t-value }\end{array}$ & $\begin{array}{l}\text { Firms having } \\
\text { high non- } \\
\text { financial } \\
\text { perf. } \\
\text { Mean } \\
\text { (n=46) } \\
\text { Sig. }\end{array}$ & $\begin{array}{c}\text { Firms } \\
\text { having low } \\
\text { general } \\
\text { perf. } \\
\text { Mean } \\
\text { (n=41) } \\
\text { t-value } \\
\end{array}$ & $\begin{array}{l}\text { Firms having } \\
\text { high general } \\
\text { perf. } \\
\text { Mean } \\
\text { (n=52) } \\
\text { Sig. }\end{array}$ \\
\hline EU & $\begin{array}{c}3.3363 \\
(-0.016)\end{array}$ & $\begin{array}{l}3.3385 \\
(0.988)\end{array}$ & $\begin{array}{c}3.2383 \\
(-1.429)\end{array}$ & $\begin{array}{l}3.4351 \\
(0.157)\end{array}$ & $\begin{array}{c}3.2179 \\
(-1.520)\end{array}$ & $\begin{array}{l}3.4285 \\
(0.132)\end{array}$ \\
\hline DS & $\begin{array}{c}3.6768 \\
(-1.958) \\
\end{array}$ & $\begin{array}{l}3.9835 \\
(0.053) \\
\end{array}$ & $\begin{array}{l}3.5517 \\
(-4.151) \\
\end{array}$ & $\begin{array}{l}4.1491 \\
(0.000) \\
\end{array}$ & $\begin{array}{l}3.6359 \\
(-2.469) \\
\end{array}$ & $\begin{array}{l}4.0137 \\
(0.015) \\
\end{array}$ \\
\hline CS & $\begin{array}{c}3.4225 \\
(-0.057)\end{array}$ & $\begin{array}{l}3.4338 \\
(0.955)\end{array}$ & $\begin{array}{c}3.1117 \\
(-3.519)\end{array}$ & $\begin{array}{l}3.7484 \\
(0.001)\end{array}$ & $\begin{array}{c}3.2632 \\
(-1.524)\end{array}$ & $\begin{array}{l}3.5556 \\
(0.131)\end{array}$ \\
\hline MCS & $\begin{array}{c}3.8557 \\
(-2.863)\end{array}$ & $\begin{array}{l}4.1895 \\
(0.005) \\
\end{array}$ & $\begin{array}{c}3.8710 \\
(-2.788)\end{array}$ & $\begin{array}{l}4.1971 \\
(0.006) \\
\end{array}$ & $\begin{array}{c}3.8741 \\
(-2.378)\end{array}$ & $\begin{array}{l}4.1571 \\
(0.020)\end{array}$ \\
\hline $\begin{array}{c}\text { Interaction term } \\
\text { EUxDSxMCS }\end{array}$ & $\begin{array}{l}48.2031 \\
(-2.237)\end{array}$ & $\begin{array}{c}57.2684 \\
(0.028)\end{array}$ & $\begin{array}{l}45.5691 \\
(-4.029)\end{array}$ & $\begin{array}{c}60.8132 \\
(0.000)\end{array}$ & $\begin{array}{l}46.3317 \\
(-3.079)\end{array}$ & $\begin{array}{c}58.4529 \\
(0.003)\end{array}$ \\
\hline $\begin{array}{c}\text { Interaction term } \\
\text { EUxCSxMCS }\end{array}$ & $\begin{array}{l}45.0428 \\
(-1.140) \\
\end{array}$ & $\begin{array}{l}49.8466 \\
(0.257) \\
\end{array}$ & $\begin{array}{l}40.3527 \\
(-3.748) \\
\end{array}$ & $\begin{array}{c}54.9346 \\
(0.000) \\
\end{array}$ & $\begin{array}{l}41.8716 \\
(-2.501) \\
\end{array}$ & $\begin{array}{l}52.0545 \\
(0.014) \\
\end{array}$ \\
\hline $\begin{array}{l}\text { Interaction term } \\
\text { EUxDSXICS }\end{array}$ & $\begin{array}{l}46.3854 \\
(-2.095)\end{array}$ & $\begin{array}{c}55.8254 \\
(0.039)\end{array}$ & $\begin{array}{l}43.6566 \\
(-3.731)\end{array}$ & $\begin{array}{c}59.4686 \\
(0.000)\end{array}$ & $\begin{array}{l}44.5129 \\
(-2.835)\end{array}$ & $\begin{array}{c}56.9689 \\
(0.006)\end{array}$ \\
\hline $\begin{array}{l}\text { Interaction term } \\
\text { EUxDSxDCS }\end{array}$ & $\begin{array}{l}48.2485 \\
(-1.931)\end{array}$ & $\begin{array}{c}56.7527 \\
(0.057)\end{array}$ & $\begin{array}{l}45.4905 \\
(-3.580)\end{array}$ & $\begin{array}{c}60.3378 \\
(0.001)\end{array}$ & $\begin{array}{l}46.6063 \\
(-2.587)\end{array}$ & $\begin{array}{c}57.7449 \\
(0.011)\end{array}$ \\
\hline $\begin{array}{l}\text { Interaction term } \\
\text { EUxCSxICS }\end{array}$ & $\begin{array}{l}43.5825 \\
(-1.121) \\
\end{array}$ & $\begin{array}{c}48.7144 \\
(0.265) \\
\end{array}$ & $\begin{array}{l}38.8857 \\
(-3.499) \\
\end{array}$ & $\begin{array}{l}53.8056 \\
(0.001) \\
\end{array}$ & $\begin{array}{l}40.3759 \\
(-2.373) \\
\end{array}$ & $\begin{array}{l}50.9092 \\
(0.020) \\
\end{array}$ \\
\hline $\begin{array}{l}\text { Interaction term } \\
\text { EUxCSxDSC }\end{array}$ & $\begin{array}{l}45.0325 \\
(-0.980)\end{array}$ & $\begin{array}{l}49.4238 \\
(0.330)\end{array}$ & $\begin{array}{l}40.4219 \\
(-3.328)\end{array}$ & $\begin{array}{c}54.3662 \\
(0.001)\end{array}$ & $\begin{array}{l}42.1396 \\
(-2.124)\end{array}$ & $\begin{array}{c}51.4029 \\
(0.036)\end{array}$ \\
\hline
\end{tabular}

According to the mean scores for the independent variables, the t-test indicated that firms with high financial performance tend to use MCS, three-way interaction between EU, DS and MCS, three-way interaction between EU, DS and ICS to a greater extent than firms with low financial performance. On the other hand, the results of the t-test showed not significant variations $(p<0.01$, two-tailed test) between the groups in terms of EU, DS, CS, interaction term EUxCSxMCS, interaction term EUxDSxDCS, interaction term EUxCSxICS and interaction term EUxCSxDSC. At the same time, the table indicated that except the EU variable, high non-financial performance firms use all the other variables more than low non-financial performance firms. Similarly, all the above variables except the EU and CS variables showed significant differences between firms with high and low general performance.

\section{Discussion and Conclusion}

The target of this study is to examine the effect of three way interaction between EU, BS and MCS on firm performance. The sample of the study comprised of top managers (general manager or vice general managers) of manufacturing enterprises ranked among the top 500 in Turkey. According to the aim of the study, four questionnaires were performed (EU,BS, MCS and performance scales) and these questionnaires were sent to 469 manufacturing firms via mail. 94 managers responded the questionnaires. The response rate was $20 \%$. In the analysis of data, factor analysis, descriptive statistic (mean and standard deviation), correlation analysis, multiple regression analysis and $t$ test were used. 
Firstly, the correlation analysis is employed to test the effect of EU, BS, MCS and interaction terms on financial, non-financial and general performance. Financial firm performance is positively and significantly correlated with DS, MCS, the EUxDSxMCS interaction term, the EUxCSXMCS interaction term, the EUxDSxICS interaction term, the EUxDSxDCS interaction term, the EUxCSxICS interaction term and the EUxCSxDCS interaction term. Non-financial firm performance are positively and significantly associated with all the above variables. Additionally, general firm performance is positively and significantly related to BS, MCS and threeway interaction variables except the EU variable.

Secondly, The multiple regression analysis was used to test the effect of EU, BS, MCS and interaction terms on general firm performance. According to regression tables of model I, II, III, it is possible to direct these evaluations towards the effects of independent variables on dependent variables: DS, MCS, the threeway interaction between EU, DS and MCS and the three-way interaction between EU, DS and ICS are important factors for general firm performance as expected. That is to say, high interaction between EU, DS and MCS and high interaction between EU, DS and ICS provides an appropriate condition for high firm performance.

Lastly, the effects of the independent variables on low and high performance individually are explained through $t$ test. The results of this analysis indicate that the independent variables varies according to low and high financial, non-financial and general firm performance. As to this, higher use of MCS, threeway interaction between EU, DS and MCS, three-way interaction between EU, DS and ICS leads to high financial performance. However, More use of all the above variables except the EU variable leads to high non-financial performance. Also, firms with high general performance use DS, MCS, three-way interaction between EU, DS and MCS, three-way interaction between EU, CS and MCS, three-way interaction between EU, DS and MCS and three-way interaction between EU, CS and DCS more than ones with low general performance.

A number of limitations of this study can be mentioned. Firstly, the sample was compose of top 500 firms in Turkey. Therefore, more comprehensive sample may be useful for future studies. Also, this study used EU, BS, MCS and three way interactions as variables affecting firm performance. Future research may include variables such as organizational size, structure, advanced technologies and culture.

\section{End Notes}

1. In the model, the interaction terms were formed by multiplying the average scores of variables.

\section{References}

Abernathy, M. A., \& Guthrie, C. H. (1994). An empirical assessment of the "fit" between strategy and management information system design. Accounting and Finance, 34, 49-66.

Acquaah, M. (2013). Management control systems, business strategy and performance: A comparative analysis of family and non-family businesses in a transition economy in Sub-Saharan Africa. Journal of Family Business Strategy, 4, 131-146.

Acquaah, M., Adjei, M.C., \& Mensa-Bonsu, I. F. (2008). Competitive strategy, environmental characteristics and performance in African emerging economies: Lessons from firms in Ghana. Journal of African Business, 9, 1, 93120.

Anthony, R.N., Dearden, J., \& Bedford, N.M. (1989). Management control systems (Sixth Ed.), Irwin.

Arachchilage, N. D. K., \& Smith, M. (2013). The effects of the diagnostic and Interactive use of management control systems on the strategy-performance relationship. JAMAR, 11, 1, 9-27.

Auzair, M., \& Langfield-Smith, K. (2005). The effect of service process type, business strategy and life-cycle stage on bureauctic MCS in service organizations. Management Accounting Research, 16, 399-421. 
Auzair, S. Md. (2011). The effect of business strategy and external environment on management control systems: $A$ study of Malaysian hotels. International Journal of Business and Social Science, 2, 13, 236-245.

Baines, A., \& Langfield-Smith, K. (2003). Antecedents to management accounting change: A structural equation approach. Accounting, Organizations and Society, 28, 675-698.

Bastian, E., \& Muchlish, M. (2012). Perceived environment uncertainty, business strategy, performance measurement systems and organizational performance. International Congress on Interdisciplinary Business and Social Science, 2012, (Icıbsos 2012).

Bouwens, J., \& Abernethy, M. A. (2000). The consequences of customization on management accounting system design. Accounting, Organizations and Society, 25, 3, 221-259.

Çetindaş, A., \& Çelik, M. (2017). İmalat işletmelerinin tedarikçi entegrasyonları ile lojistik performansları arasındaki ilişki üzerine çevresel belirsizliğin düzenleyici rolü. Toros Üniversitesi iiBF Sosyal Bilimler Dergisi, 4, 7, 131-145.

Chenhall, R. H. (1997). Reliance on manufacturing performance measures, total quality management and organizational performance. Management Accounting Research, 8, 187-206.

Chenhall, R. H. (2003). Management control system design within its organizational context: Finding from contingencybased research and directions for the future. Accounting, Organization and Society, 28, 2-3, 127-168.

Chong, V. K., \& Chong, K. M. (1997). Strategic choices, environmental uncertainty and SBU performance: A note on the intervening role of management accounting systems. Accounting and Business Research, 27, 4, 268-276.

Desarbo, W. S., Benedetto, A. D., Song, M., \& Sinha, I. (2005). Extending the Miles and Snow strategic framework: Strategic Types, capabilities, environmental uncertainty, and firm performance. Strategic Management Journal, $26,47-74$.

Dess, G. G., \& Davis, P. S. (1984). Porter's (1980) generic strategies as determinants of strategic group membership and organizational performance. The Academy of Management Journal, 27, 3, 467-488.

Dropulić, I. (2013). The effect of contingency factors on management control systems: A study of manufacturing companies in Croatia. The 6th International Conference "The Changing Economic Landscape: Issues, Implications and Policy Options", Juraj Dobrila University Of Pula, Faculty Of Economics and Tourism, Http://Oetconference2013.Estudy-Oet.Net/ Issn1331 - 677x (Udk 338) May 30th - June 1st 2013.

Frigotto, M. L., Coller, G., \& Collini, P. (2013). The strategy and management control systems relationship as emerging dynamic process. The Journal of Management and Governance, 17, 631-656.

Gani, L., \& Jermias, J. (2012). The effects of strategy-management control system misfits on firm performance. Accounting Perspectives, 11, 3, 165-196.

Govindarajan, V. (1988). A contingency approach to strategy implemantation at the business-unit level: Integrating administrative mechanisms with strategy. Academy of Management Journal, 31, 4, 828-853.

Govindarajan, V., \& Fisher, J. (1990). Strategy, control systems, and resource sharing: Effects on business-unit performance. The Academy of Management Journal, 33, 2, 259-285.

Gschwantner, S., \& Hiebl, M. R. W. (2016). Management control systems and organizational ambidexterity. Journal of Management Control, 27, 4, 371-404.

Gupta, A. K., \& Govindarajan, V. (1984). Business unit strategy, managerial characteristics, and business unit effectiveness at strategy implementation. Academy of Management Journal, 27, 1, 25-41.

Hambrick, D. D. (1980). Operationalizing the concept of business level strategy in research. Academy of Management Review, October, 567-576.

Hopwood, A. G. (1976). Accounting and human behavior. Englewood Cliffs, NJ: Prentice-Hall.

Iqbal, S., \& Sharma, R. R. K. (2012). A study of organizatıon strategies, structures, culture dimensions and management control systems of various retail formats. International Journal of Business Strategy, 12, 1, 39-46.

Junqueira, E., Dutra, E. V., Filho, H. Z., \& Gonzaga, R. P. (2016). The effect of strategic choices and management control systems on organizational performance. R. Cont. Fin. - Usp, São Paulo, 27, 72, 334-348.

Kaplan, R. S. (1983). Measuring manufacturing performance: A new challenge for managerial accounting research. The Accounting Review, 686-705.

Kohli, A. K., \& Jaworski, B. J. (1990). Market orientation: The construct, research propositions, and managerial implications. Journal of Marketing, 54, 2, 1-18.

Lenz, R. T. (1980). Environment, strategy organization structure and performance: Patterns in one industry. Strategic Management Journal, July/September, 209-226. 
Malmi, T., \& Brown, D. A. (2008). Management control systems as a package-opportunities, challenges and research directions. Management Accounting Research, 19, 287-300.

Merchant, K. A. (1985). Control in business organizations. Boston: Pitman.

Merchant, K. A., \& Bruns, W.Jr. (1986). Measurements to cure management myopia. Business Horizons, May-June, 5664.

Miles, R. E., \& Snow, C. C. (1978). Organizational strategy, structure and process. McGraw-Hill: New York.

Miller, D., \& Friesen, P.H. (1982). Innovation in conservative and entrepreneurial firms: Two models of strategic momentum. Strategic Management Journal, 3, 1-25.

Miller, D. (1988). Relating Porter's business strategies to environment and structure: Analysis and performance implications. Academy of Management Journal, 31, 2, 280-308.

Milliken, F. J. (1987). Three types of perceived uncertainty about the environment: State, effect, and response uncertainty. The Academy of Management Review, 12, 1, 133-143.

Naranjo-Gil, D. (2016). Role of management control systems in crafting realized strategies. Journal of Business Economics \& Management, 17, 6, 865-881.

Nilsson, F. (2002). Strategy and management control systems: a study of the design and use of management control systems following takeover. Accounting and Finance, 42, 41-71.

Ouchi, W. G. (1980). Markets, bureaucracies, and clans. Administrative Science Quarterly, 25, 129-141.

Porter, M. E. (1980). Competitive strategy. New York: Free Press.

Porter, M. E. (1985). The competitive advantage: Creating and sustaining superior performance. New York: Free Press.

Sim, K. L., \& Koh, H. C. (2001) Balanced scorecard: A rising trend in strategic performance measurement. Measuring Business Excellence, 5, 2, 18-26.

Simons, R. (1987). Accounting control systems and business strategy: An empirical analysis. Accounting, Organizations and Society, 12(4), 357-374.

Simons, R. (1994). How new top managers use control systems as levers of strategic renewal. Strategic Management Journal, 15, 3, 169-189.

Simons, R. (1995). Levers of control: How managers use innovative control systems to drive strategic renewal. Boston: Harvard Business School Press.

Simons, R. (2000). Performance measurement \& control systems for implementing strategy. New Jersey: Prentice Hall.

Tessier, S., \& Otley, D. (2012). A conceptual development of Simons' levers of control framework. Management Accounting Research, 23, 3, 171-185.

Theriou, N., Maditinos, D., \& Theriou, G. N. (2017). Management control systems and strategy: A resource based perspective. Evidence from Greece. International Journal of Business and Economic Sciences Applied Research, $10,2,35-47$.

Thomas, J. H. (1990). Performance measurement for competitive excellence. In Kaplan, R.S. (Ed.). Measures for manufacturing excellence. Boston, Massachusetts: Harvard Business School Press.

Tsamenyi, M., Sahadev, S., \& Qiao, Z. S. (2011). The relationship between business strategy, management control systems and performance: Evidence from China. Advances in Accounting, 27, 1, 193-203.

Uzkurt, C. (2002). Çevresel belirsizliklere karşı rekabet avantajı yakalamada stratejik esnekliğin rolü ve firma performansına etkileri. Osmangazi Üniversitesi Sosyal Bilimler Dergisi, 3,1,1-20.

Van Der Stede, W. A. (2000). The relationship between two consequences of budgetary controls: Budgetary slack creation and managerial short-term orientation. Accounting, Organizations and Society, 25, 6, 609-622.

Widener, S. K. (2007). An empirical analysis of the levers of control framework. Accounting, Organizations and Society, $32,757-788$.

Wruck, K. H., \& Jensen, M. C. (1998). The two key principles behind effective TQM program. European Financial Management, 4, 401-423.

Young, S. M., \& Selto, F. H. (1991). New manufacturing practices and cost management: A review of the literature and directions for research. Journal of Accounting Literature, 10, 265-298. 
This Page Intentionally Left Blank 